\title{
Estimation of Solar Energy Potential from Rooftop of Punjab Government Servants Cooperative Housing Society Lahore Using GIS
}

\author{
Muhammad Luqman, Sajid Rashid Ahmad, Samiullah Khan, Usman Ahmad, Ahmad Raza, \\ Farkhanda Akmal \\ Institute of Geology, University of the Punjab, Lahore, Pakistan \\ Email: $\underline{\text { m luqman1@yahoo.com }}$
}

Received 18 April 2015; accepted 26 May 2015; published 29 May 2015

Copyright (C) 2015 by authors and Scientific Research Publishing Inc.

This work is licensed under the Creative Commons Attribution International License (CC BY).

http://creativecommons.org/licenses/by/4.0/

(c) (i) Open Access

\begin{abstract}
Pakistan has a severe electricity load shading problem. Government is trying to find out all ways for electricity generation. Alternative energy board is working to find out the energy potential using all alternative resources. Board has an objective to produce $9700 \mathrm{MW}$ by 2030 to overcome load shading problem. A research was designed to find out the solar energy potential as an alternative source of energy from rooftops of residential areas in district Lahore. Punjab Governments servants housing society Lahore is selected. The society has minimum slope, aspect and shadows effects on the roofs. Also houses in PGSHS have same house structures and good town plan. A few portions of roofs are digitized to measure the available rooftop area for Photovoltaic panel's installation. GIS models are used to find out solar energy potential monthly as well as yearly for the year of 2014. The potential estimated is $39,613,072 \mathrm{kWh} /$ year. The monthly total energy consumption of the society is $347,140 \mathrm{kWh}$ which is only $11 \%$ of energy production from PV solar panels. As the estimated energy is 9 times than the energy demand of the society, extra energy can be used in local/national electricity transmission grid. Solar PV energy would be supplement to compensate energy shortfall in local area.
\end{abstract}

\section{Keywords}

Photovoltaic, Alternative Energy, Pakistan, $\mathrm{CO}_{2}$ Emission, Rooftop 


\section{Introduction}

On the earth, the biggest source of energy is the sun. Solar flux is more than many times of human need. Solar energy is a essential part of life. Without it, live would be impossible. Annual average solar energy on entire planet may produce $1.3-1.4 \mathrm{~kW} / \mathrm{m}^{2}$ electric energy [1] [2]. Intensity of solar flux depends upon geographic location, weather condition, altitude and diurnal variation. The minimum solar potential available worldwide is $0.06 \mathrm{~kW} / \mathrm{m}^{2}\left(\sim 500 \mathrm{kWh} / \mathrm{m}^{2}\right.$ per year) to the highest flux of $0.25 \mathrm{~kW} / \mathrm{m}^{2}\left(\sim 2200 \mathrm{kWh} / \mathrm{m}^{2} /\right.$ year $)$ in deserts areas of Africa and Australia [3].

\section{Aims and Objectives}

The aim is to find out photovoltaic solar energy potential from a suitable site in Lahore City having maximum solar irradiance and minimum slop, shadow and aspect in rooftops using GIS technique.

This study proposes Geographic information system techniques and modeling to identify optimal place to estimate solar energy potential from the rooftop of the site in district Lahore. Optimal site in this study is consider that site which have very low topographic variation and very low slop, aspect and shadow affects at the rooftops of the buildings.

The objective is to estimate solar energy potential from rooftops of selected sites. The selected site would be residential area. The output generated energy would be consumed by these houses.

The second object of the study is to find out whether there is extra energy after the uses of rooftop owners of the site, to connect it to local electricity grid network. This energy would be utilized from other consumers.

This study also objects to find out how and how much carbon emission would be reduced by using solar energy technologies.

Energy short fall is a burning issue of Pakistan in present condition. Every field of life is facing energy shortfall problem especially residential area which is focus of our study. In June 2012, peak energy demand was 17,861 MW and peak energy generation capacity was 14,317 MW [4]. To compensate short fall of $3544 \mathrm{MW}$, consumers use other sources of energies, which are very costly, so solar energy is a solution for energy generation.

Arifeen [5] expressed in his article that electricity demand had increased by $80 \%$ in last 15 years. According to Pakistan Water and Power Development Authority (WAPDA), energy demand would be 40,000 MW by 2020 in Pakistan. An analysis of energy demand shows that there is $4.8 \%$ demand in last five years but now expected demand will be $8 \%-10 \%$ per year, so $7 \%-8 \%$ production is necessary to fulfill energy consumption in the future. For the energy production, some dams are being constructed in the country. Diamer Basha, Buniji and kohala Dams are some of them having capacity of $4500 \mathrm{MW}, 7100 \mathrm{MW}$ and $11 \mathrm{MW}$ respectively. At present, about 300 small and mini hydropower plants are installed by the private and public sector in the northern hilly areas of Pakistan, supplying electricity to local consumers.

Unfortunately, all resources had not been utilized in Pakistan for energy production. There is lack of determination and management. In June 2011, a project for the construction of 12 small dams in different parts of the country was signed. Their completion date was 2013. However, not a single dam has been completed yet. The lack of planning is the big cause of energy crises. No practical work has been done for future energy demand. All plans died in paper work. Pakistan has a lot of resources for energy production. Hydro power energy is the cheapest energy, but no dams have been constructed from many years. Pakistan is granted by a huge amount of coal, but it is not utilized for energy production. A vast loss of electricity through transmission lines and theft produces an energy shortage. According to labor department, about 800,000 labors have lost their jobs. Many kids died in hospitals due to load shedding.

Electricity in Pakistan is being produced by using all conventional means of sources like hydro power, gas, oil and nuclear energy. Oil and gas are expensive sources. There was not any department for renewable energy till 2003; then, an autonomous board was made by government of Pakistan. This board is Alternative Energy Development Board (AEBD). The main job of this board is to find out all means of renewable energy and utilize them for energy production. This board has to achieve 5\% share of power generation of total demand of electricity in country by 2030 [6].

Solar radiations are 6000 times enough for total world energy demand and these radiations can fulfill dozen time energy demand of the world using current technologies [7]. Some land of Pakistan is located near tropical region of the earth. Long sun shine hours and high solar irradiance make Pakistan suitable for solar energy production. 
The average global irradiance is about $200-250 \mathrm{Watt} / \mathrm{m}^{2}$ per day over the horizontal surface. It is $1.9-2.3$ $\mathrm{MWh} / \mathrm{m}^{2}$ per year [6]. The desert areas of Pakistan are Cholistan and Thar receiving a high amount of flux.

\section{Literature Review}

Photovoltaic panels' installation has many limitations all over the world. There are many models to estimate solar flux over a geographical area. All models have some parameters. All models have to face these limitations and challenges. Review of these challenges and limitations are as under:

Slope of rooftop is very important factor for installation of solar PV. Flat areas receive more radiations [8][11]. Rooftop having slop have directions. These directions on roof are called aspect of that roof. If these directions are not along the path of the sun then radiations will be affected [8]. Radiations fall with three ways on surface of the earth and roof. Those radiations which strictly direct on the rooftop or roof surface are called direct normal irradiance. The More the radiations more the energy produced. These radiations have a role for energy generation [12]-[14]. If modules aim to install in open land, then the project land should be near to roads for easy transportation of infrastructure. Project area close to roads results less cost of infrastructure construction, installation and maintenance [13] [14]. Distance of PV modules to transmission grid matters [10] [12]. Solar panel's efficiency may decrease due to fog, mist and dust [11]. Similarly environmental sensitive areas, Weather conditions, flood pathways, Dam sites and cultural and heritage sites also should consider for PV installation [11] [13].

Johnson and Armanino [7] conduct a study in Marin County, California State to estimate solar PV potential from rooftop of the county. There is so much variance in topography of county. GIS models and other four type of data were used to estimate solar potential from rooftop. Shadows effect was the biggest challenge of the study. Rooftop areas were considered in this study rather than whole county land. As a result of the study there was 58 MW potential to produce energy from PV in commercial sector, $25 \mathrm{MW}$ from parking lots and $13 \mathrm{MW}$ form institutional facilities.

National Renewable energy laboratory (NREL) commissioned a study in U.S. at national level by working with Navigant Consulting Inc. (NCI) to estimate PV potential [15]. The result was more than $500 \mathrm{GW}$ of energy potential from the rooftop by using PV.

National Renewable Energy Laboratory (NREL) completed a project in 2007 to find out solar and wind potential in Pakistan and Afghanistan. For estimating solar potential, European meteorological satellite data of three years' time span was used. Three types of irradiances, direct, diffuse and scattered were calculate at 10 KM and $40 \mathrm{KM}$ grids for the entire country of Pakistan. Software named "GsT" is available on NREL website [16].

\section{GIS Models for Solar Analysis}

Many GIS models had been used for estimation of solar potential. Some models have good results and are being used presently. Different models use different kind of data and different operation systems and software models. Some of these models are as under:

A GIS based model, SolarFlux, was developed in ESRI software environment by Hetrick et al. [17]. Horizon shading, solar angle, surface orientation, atmospheric conditions and solar flux data is used in this software, to estimate solar energy potential of a specific area.

Another model by developed by Hofierka and Súri [18] for solar analysis in GIS Genasys software. This software was developed in Automation Markup language script. This algorithm works similar to Solar Flux model.

Mostly used software, "ArcGIS", is software of Environmental Sciences Research Institute (ESRI). It has a toolset for analyzing. In the toolset "Solar analyst" is one of those extensions. It was developed by the model of Fu and Rich [19].

\section{Methodology}

\subsection{Study Area}

The Punjab Government Servants Housing Scheme Lahore was chosen due to its unique design and suitability for PV modules installation. Figure 1 is depicting surroundings of study area. 
This society is centered at $31.40^{\circ} \mathrm{N}, 74.17^{\circ} \mathrm{E}$ and total area $524,692 \mathrm{~m}^{2}$. As Lahore is a warm city so this society has a high irradiance have a high potential for PV energy generation. The average is temperature range between average high $30.8^{\circ} \mathrm{C}$ and average low $17.8^{\circ} \mathrm{C}$ (source: NOAA (1961-1990). In 2010, a total of 738 millimeters rain fall was recorded. The society is suitable for PV installation due to least topographic variability. Nearly all the roofs are of same height. There are four types of houses size. The classes are as:

Each Class has the same architecture design so all the roofs also have same design. The classes and number of houses are summarized in Table 1. This make easy and suitable place for PV installation. The study area was selected because Lahore has the very high PV potential across the world. The study was done using all the free data available.

Google Earth imagery is used for digitizing rooftops. High resolution Google Earth imagery was downloaded using Google Earth Pro of the date of March 18, 2014. Screen shot of the imagery is shown in Figure 2. Image

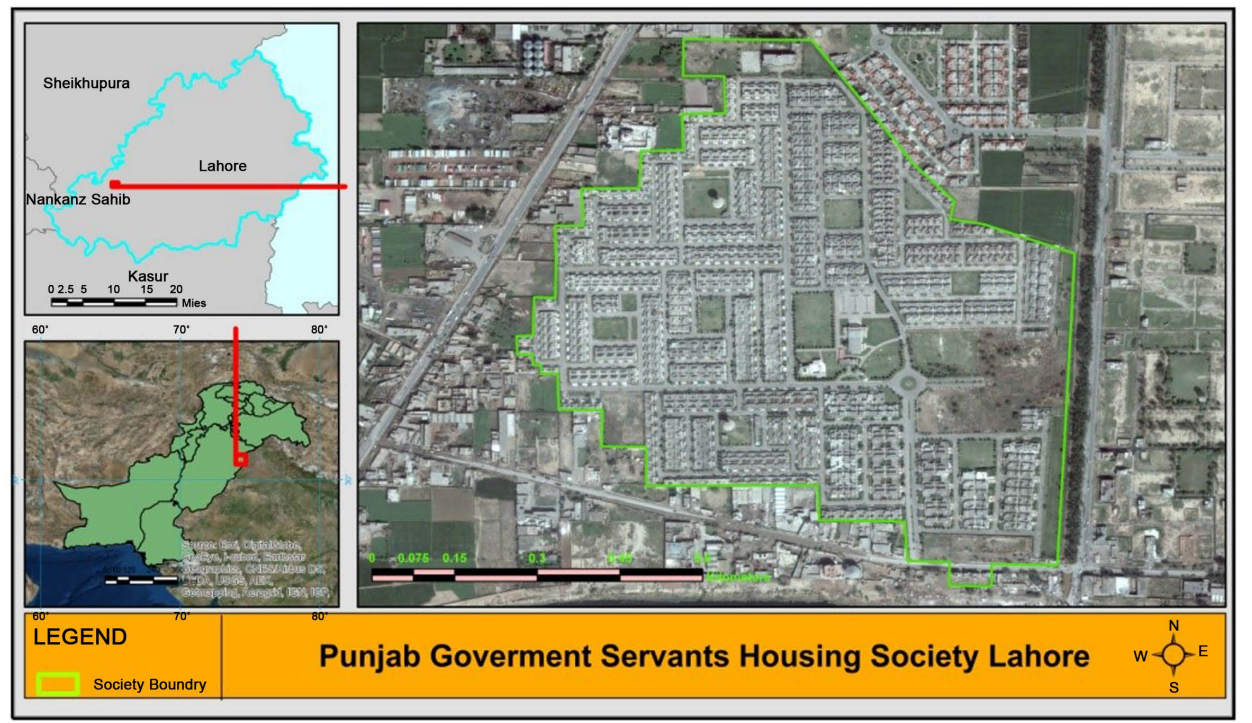

Figure 1. Study area.

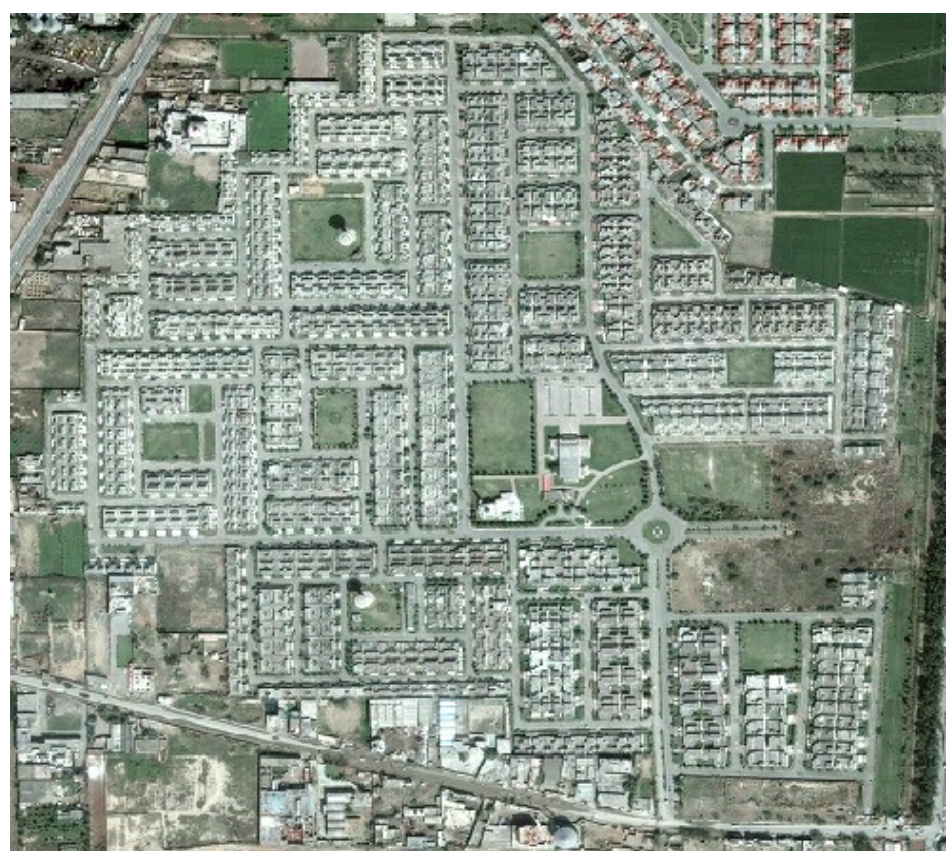

Figure 2. Aerial imagery of study area (Screen Shot of Google Earth Imagery). 
Table 1. Study area buildings and types (source: http://www.pgshf.gop.pk/files/lahore.asp).

\begin{tabular}{cc}
\hline House Size & No. of Houses \\
\hline 5-Marla $\left(\mathbf{1 2 6 . 4 7} \mathbf{M}^{\mathbf{2}}\right)$ & 598 \\
7-Marla $\left(\mathbf{1 7 7 . 0 5} \mathbf{M}^{\mathbf{2}}\right)$ & 334 \\
$\mathbf{1 0 - M a r l a ~}\left(\mathbf{2 5 2 . 9 3} \mathbf{M}^{2}\right)$ & 304 \\
1-Kanal $\left(\mathbf{5 0 5 . 8 6} \mathbf{M}^{\mathbf{2}}\right)$ & 107 \\
\hline
\end{tabular}

has zero cloud cover and best for digitizing rooftops. This image was then georefred according to Google earth coordinates In Geographic coordinates system WGS84. ArcGIS 10.1 was used to Georef image.

Google Earth imagery is used as a base map to digitize rooftops. The polygons were digitized at a zoom level of 1:250. Example of digitized rooftops is shown in Figure 3. Only a specific portion of rooftops is calculated. Not all the rooftop is digitized. Same size of area is selected from the houses of same size. Some Commercial buildings and school rooftop also digitized but a small portion not all available roof top. The mounts of rooftop are digitized so there is no shadow problem on selected area.

Only roofs were selected for PV installation during digitization which meets the following criteria:

As south, southeast and south west direction is best for PV installation, only buildings having required orientation were selected during digitization. There were no tilted roofs in study area. All buildings had flat surfaces, so orientation is not big issue for PV installation.

No shaded rooftop area was selected in this study. All the selected roofs receive direct solar radiations. Rooftop areas shaded by other buildings, structures or vegetation that affected the solar yield were not included in the study.

Those buildings having HVAC systems, air vents, chimneys etc., were not included in study area. No building had HVAC system nor chimneys etc. in study area.

DEM data was not helpful for slope and aspect calculations. A survey was conducted to collect elevation data manually for a few rooftops. Garmin GPS was used to collect elevation data. This Elevation data was entered in rooftops. Average elevation was entered to rooftops other than surveyed. Then these polygons were converted to raster to using polygon to raster tool in ArcGIS toolbox using elevation data as a field.

The survey was necessary to find out the average elevation of the study area for the calculation of annual incoming solar radiations. To understand geography, topography and rooftop shapes survey was conducted.

During survey it was noticed that nearly all the roofs have mounts on their roofs. These are only for security purpose that no one can enter in the house from down stairs. These mounts do not have any other use. So these mounts were selected for the PV installation. The mounts same as shown in Figure 4, were selected during survey of the study area.

Garmin GPS was used to find out elevation in the society. About 8 points were taken and average elevation was 202 Meters of study area. Forty bills were captured with a digital camera. As described above there are four types of houses in the study area having different sizes and different electricity load so it was necessary to collect data for all types.

Raster made from survey data was used as input to calculate slope and aspect in ArcGIS. Slope and aspect tools were used in ArcGIS 10.1 tool box. The results were aspect and slope as a raster. The aspect was calculated clockwise from north $0^{\circ}-359.9^{\circ}$ in degrees measured and was shown in Figure 5. While the inclination was calculated from $0^{\circ}-90^{\circ}$ in degrees as shown in Figure 6 .

GIS model is a convenient way to generate solar radiation potential maps and there spatial relation to other data [19]. In this study, ESRI's ArcGIS's tool is used for GIS modeling in this study to calculate solar radiations. The main input for this tool is a Raster. This raster was made up of digitized roof polygons with average elevation as a field to convert it to raster using polygon to raster conversion tool from ArcGIS tool box.

Electricity rate and bill data was collected from Lahore Electric Supply Company (LESCO) website. LESCO provides electricity to entire division as well as Lahore city.

\section{2. $\mathrm{CO}_{2}$ Emission Reduction}

Carbon contributes about $80 \%$ of all greenhouse gases which causes global warming [20]. Carbon would causes 


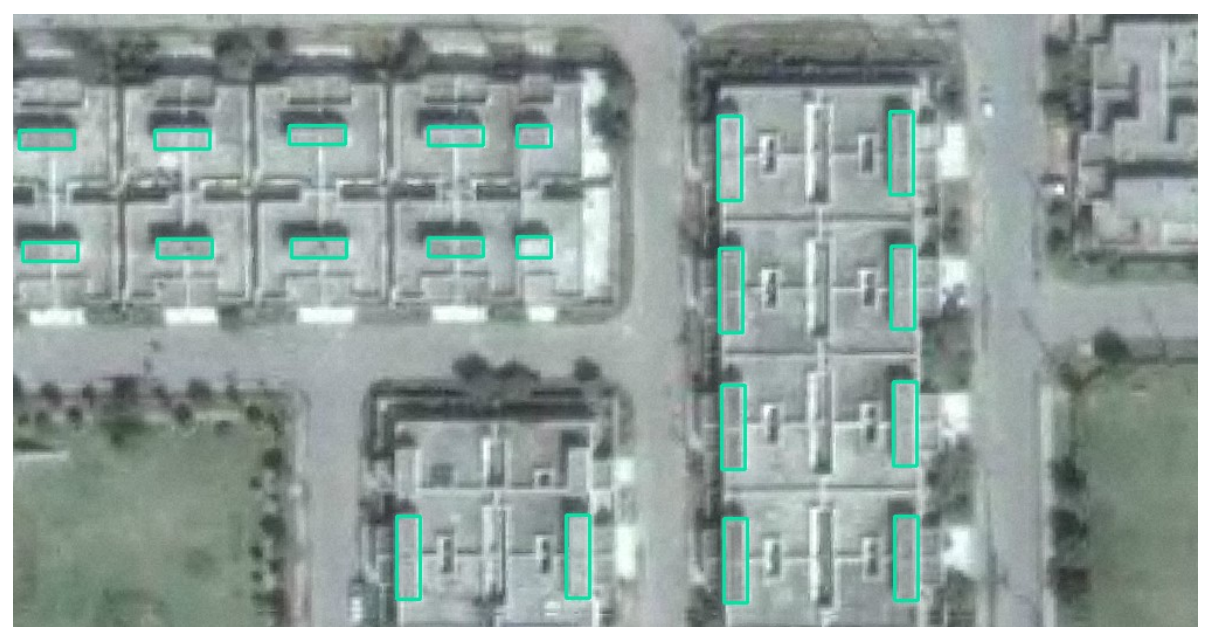

Figure 3. Sample set of rooftops (Screen Shot in ArcGIS).

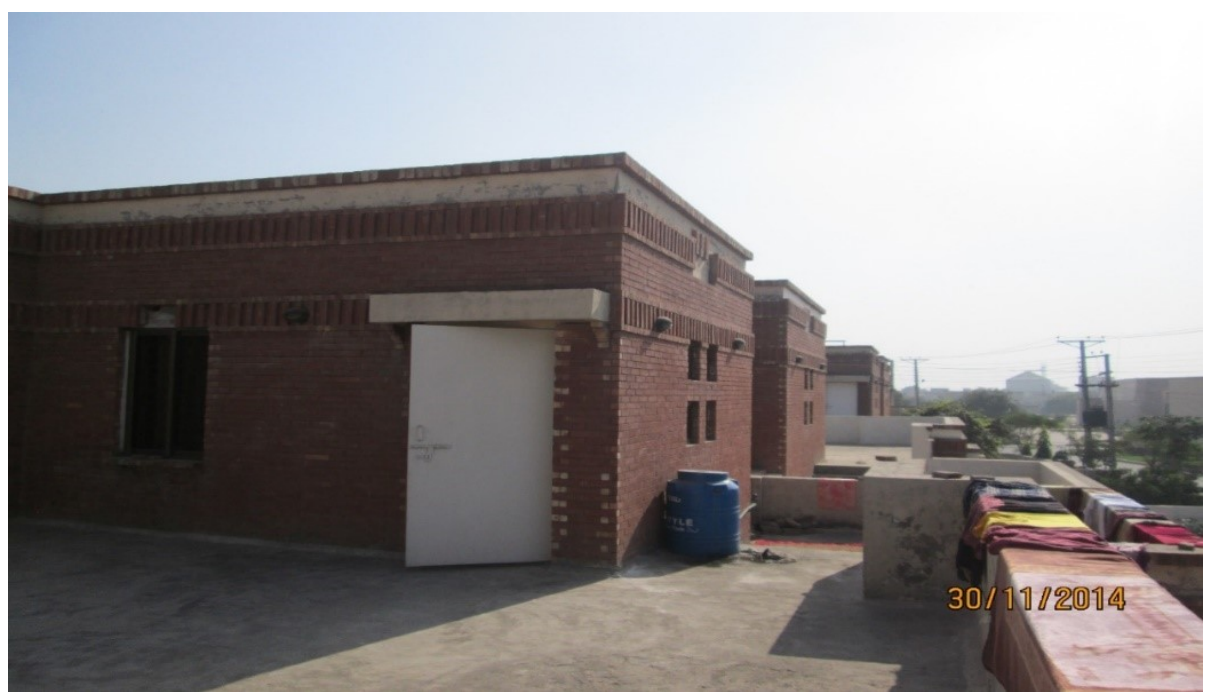

Figure 4. Selection of roof mounts (Survey and Captured by Author).

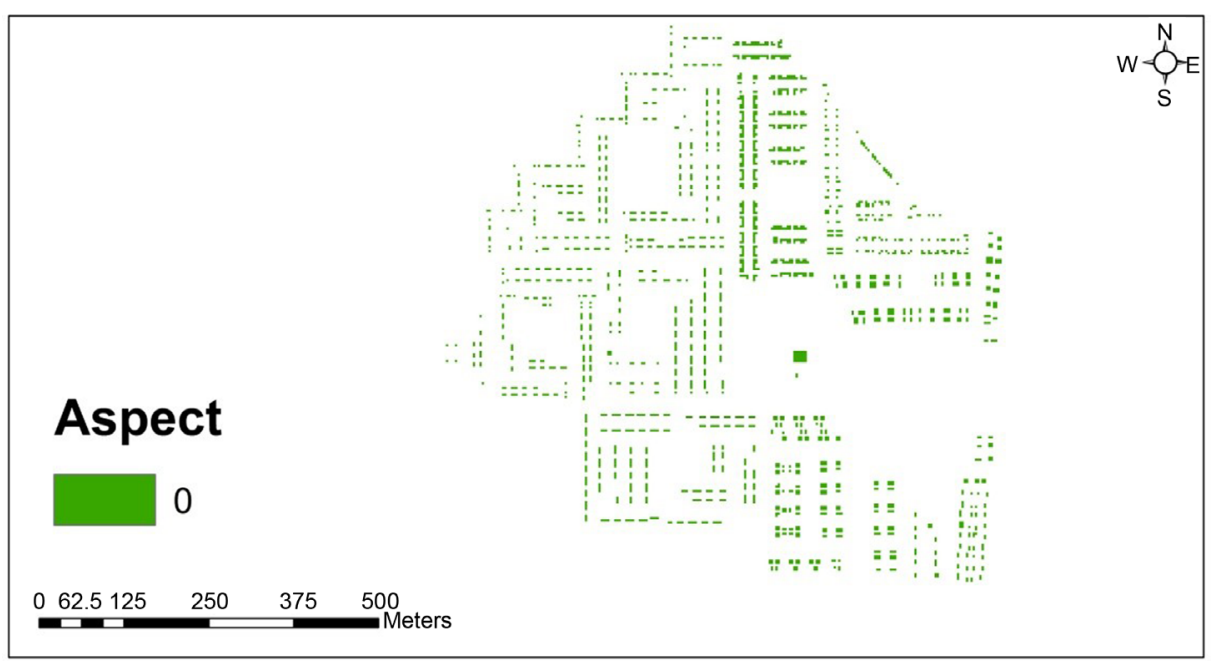

Figure 5. Map showing aspect of rooftops study area (Analysis in ArcGIS). 


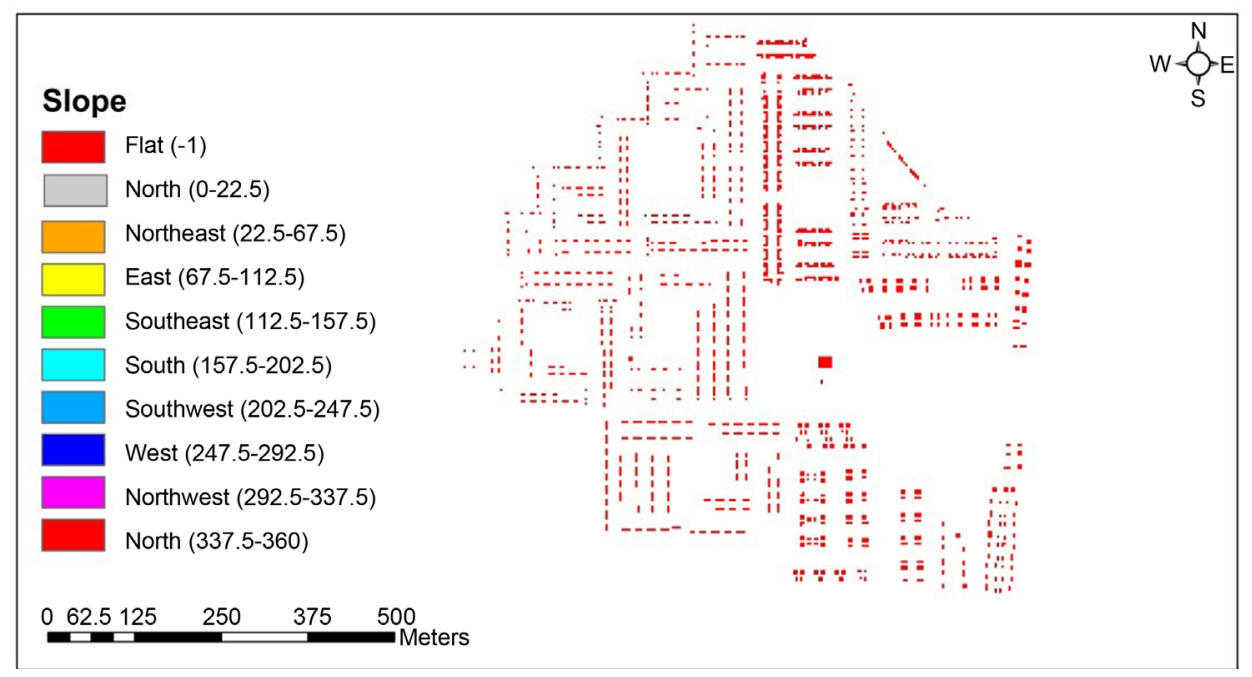

Figure 6. Map showing slop rooftops of study area (Analysis in ArcGIS).

half of climate change with in next century. Carbon emission is increasing day by day by the increasing demand of energy. Renewable energy technologies help to reduce Carbon emission. These technologies reduce less amount of carbon dioxide than fossil fuels. Solar energies produce low amount of energy as shown in Table 2.

Approximately $6.9 \times 10^{-4}$ metric tons of $\mathrm{CO}_{2}$ are emitted for the generation of $1 \mathrm{kWh}$ of electricity.

$1 \mathrm{kWh}$ of solar energy $=6.9 \times 10^{-4}$ metric tons of $\mathrm{CO}_{2}$ reduction

\section{Results}

Average output solar energy potential in the study area for the year of 2014 is $1448 \mathrm{kWh} / \mathrm{m}^{2} /$ year as shown in Figure 7. All the roofs have same slop and aspect so every meter of the roofs of the study area would produce same amount of energy from solar flux.

After digitization rooftop area all the areas were calculated for individual building. A field was added to classify digitized polygons according to size of house. House size data was entered against digitized polygons.

To calculate terrain horizon, day length, global horizontal irradiance and temperature of the study area solargis (2014) was used. Solargis is a model to estimate solar radiations of a specific area all over the globe. Data of 4 geostationary satellite is utilized for estimation. Astronomical data and terrain data is also used by solargis in its model. In this study, solargis was used to find out some important factors which are necessary for our PV installation system.

Table 3 shows the all selectable area to install solar panel on the roofs. As generally all roof area is available but we suggest a small portion of roof for subjected purpose. House mounts are best suggested area.

To measure terrain horizon, solargis used STRMv2 data. In Figure 8, path of the sun is shown over the year of 2014 at study area. Three paths of sun are shown in the figure in three curves by using gray line. The lowest gray path of sun is during winter solstices, middle curve during equinox and top curve during summer solstices.

The sun curves shows that sun have low horizon during winters and high horizon in summers at the study area. Also all the maximum energy falls in south aspect of the horizon.

The zenith angle is the angle between the sun and the vertical perpendicular drawn upon a particular area. The zenith angle is like elevation angle but it is measured from the vertical rather than from the horizontal, thus making the zenith angle $=90^{\circ}$-elevation of sun from horizon.

It is clear than the sun has very low zenith angle during summer solstice and high zenith angle at vernal equinox. Solar zenith angle is also related do day time. The greater the zenith angles the lesser the day time hour and vice versa as it is clear in Figure 9.

Global solar irradiations are total radiations on the horizontal surface on earth. These radiations are sum of all radiations like direct normal irradiance, diffuse irradiance and ground reflected radiations. Ground reflected radiations are negligible. Both diffuse and direct radiations are shown in Figure 10 of study area. These are 


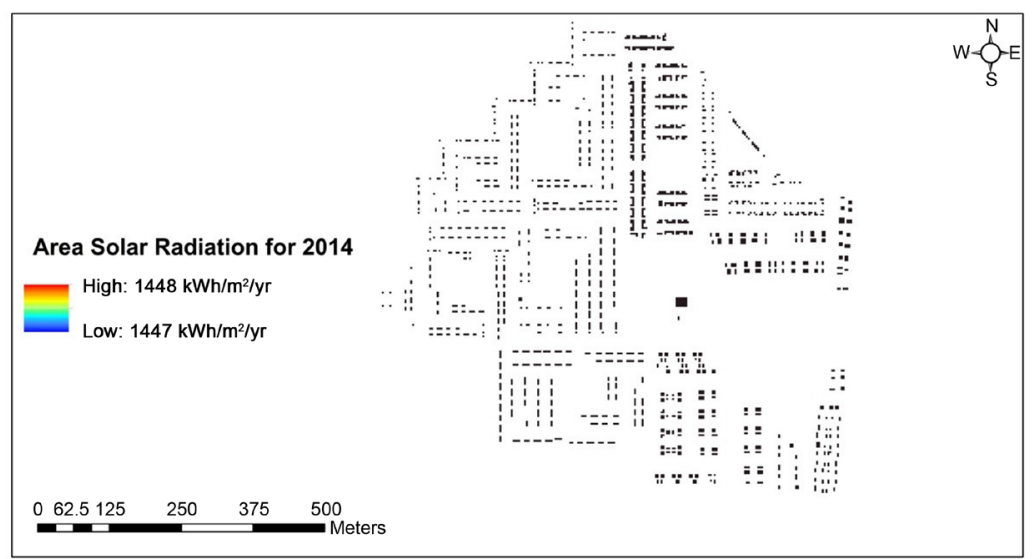

Figure 7. Annual solar radiation calculated for 2014 (Analysis in ArcGIS).

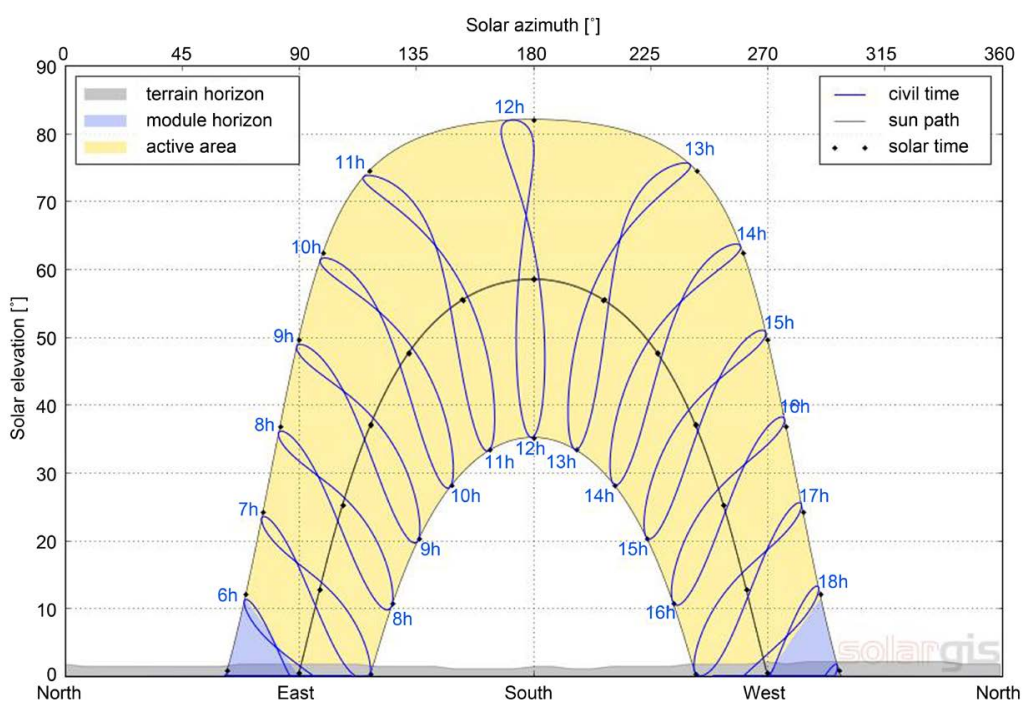

Figure 8. Terrain horizon at punjab government servants housing society Lahore (Source: solargis).

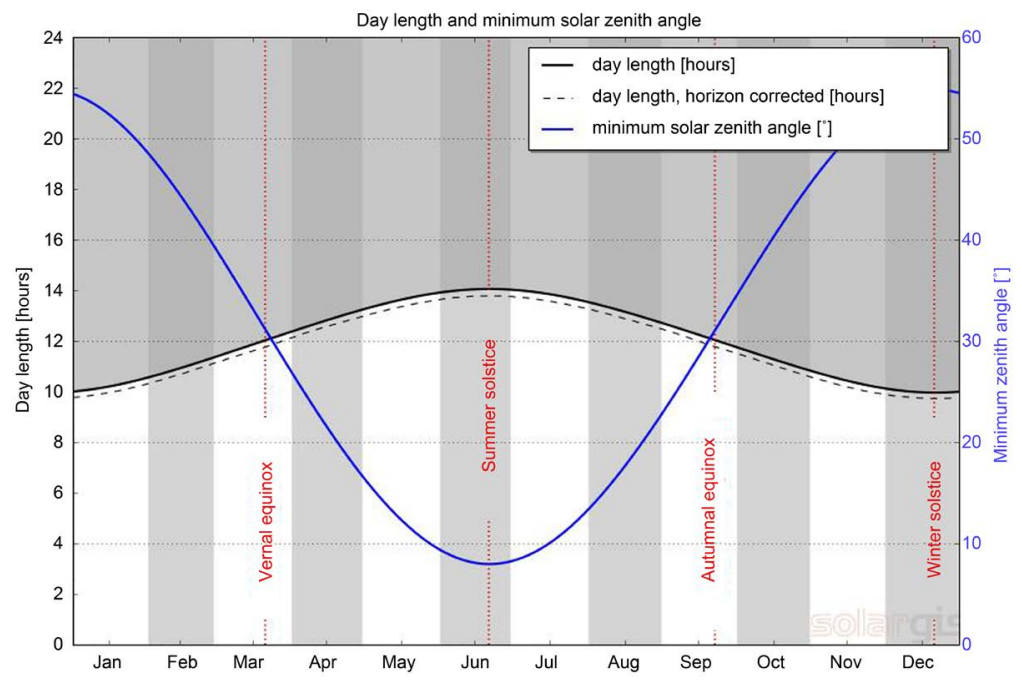

Figure 9. Day length and zenith angle at PGSHS Lahore (Source: solargis). 


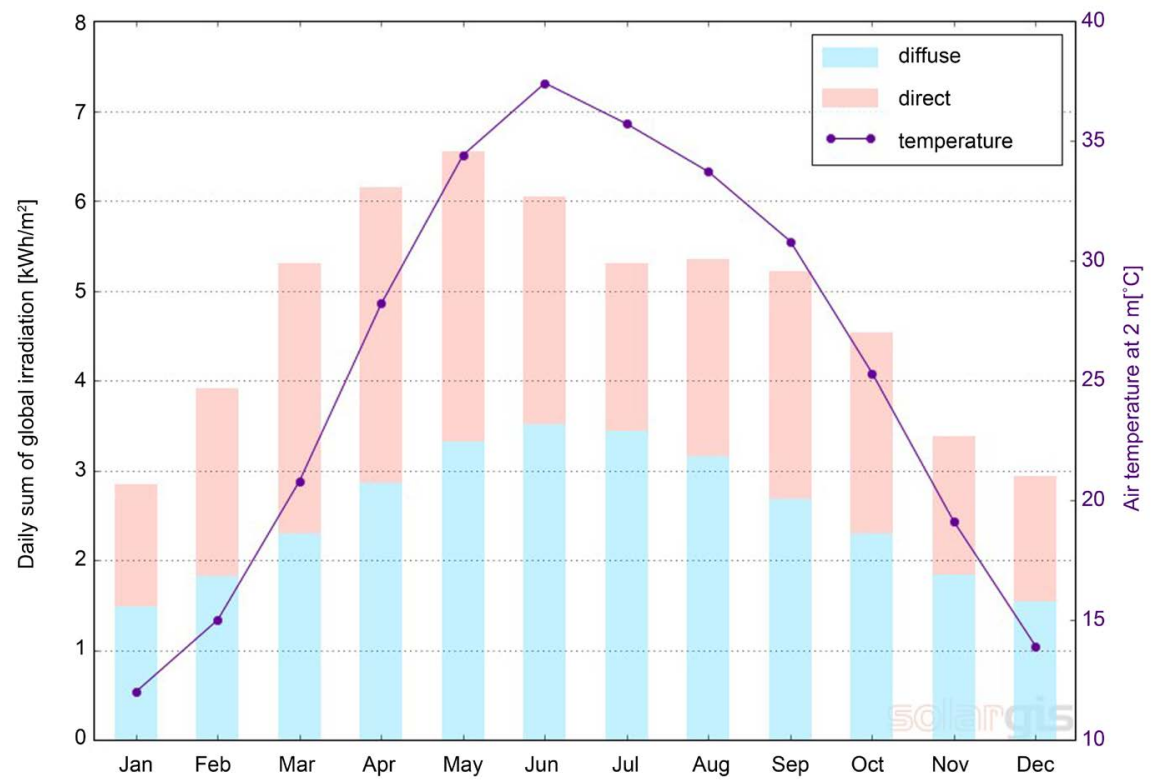

Figure 10. Global horizontal irradiation and air temperature at Punjab government servants housing society Lahore (Source: solargis).

Table 2. Carbon emissions from different sources of energy [21].

\begin{tabular}{rccccc}
\hline Energy Source & Fossil Fuels & Solar & Wind & Hydro & Biogas \\
\hline $\begin{array}{c}\text { Carbon emissions } \\
(\mathrm{g} / \mathrm{kWh} \text { generated })\end{array}$ & 504 & 99 & 10.2 & 10 & 11 \\
\hline
\end{tabular}

Table 3. Suitable rooftop area by general building type.

\begin{tabular}{ccccc}
\hline Sr. \# & House Size & $\begin{array}{c}\text { Average Digitized Roof Area } \mathrm{m}^{2} \\
\text { Per House }\end{array}$ & $\begin{array}{c}\text { Total Digitized Roof } \\
\text { Area } \mathrm{m}^{2} \text { All Houses }\end{array}$ & \multicolumn{2}{c}{$\begin{array}{c}\text { Percentage of Total } \\
\text { Area }\end{array}$} \\
\hline 1 & 5-Marla $\left(126.47 \mathrm{M}^{2}\right)$ & 19 & 6674 & $1.27 \%$ \\
2 & 7-Marla $\left(177.05 \mathrm{M}^{2}\right)$ & 29 & 5089 & $0.97 \%$ \\
3 & 10-Marla $\left(252.93 \mathrm{M}^{2}\right)$ & 31 & 4860 & $0.93 \%$ \\
4 & 1-Kanal $\left(505.86 \mathrm{M}^{2}\right)$ & 37 & 10,212 & $1.94 \%$ \\
5 & Other & 60 & 541 & $0.10 \%$ \\
\end{tabular}

maximum in May, and minimum the month of January. The more the global irradiations the more the electric power generation. It is clear there would be maximum power generation in May and minimum in January.

Air temperature at 2 meters (TEMP) data was gained and calculated by solargis from NOAA NCEP data sources. Air temperature is available from solargis for the period from January 1994 to the present time.

Site: Lahore, Pakistan, latitude/longitude: $31.4052^{\circ} \mathrm{N} / 74.1661^{\circ} \mathrm{W}$

PV system: $1.0 \mathrm{kWp}$, crystalline silicon, fixed free

Azimuthal angle: $180^{\circ}$ (south)

Inclination: 30

If all suitable and estimated rooftop area is installed with solar PV panels the total power generation from Class D, 5 Marla houses would be $804,773 \mathrm{kWh} / \mathrm{m}^{2}$ monthly and $9,657,278 \mathrm{kWh} / \mathrm{m}^{2}$ annually. Similarly $7,367,783 \mathrm{kWh} / \mathrm{m}^{2}$ would be produced from 7 Marla, 7,032,420 kWh $/ \mathrm{m}^{2}$ from 10 Marla, 14,776,764 kWh/m from 1 Kanal and $782,827 \mathrm{kWh} / \mathrm{m}^{2}$ would be produced annually. Table 4 shows the detail for the potential of each class and total area. 
The average electricity is calculated from 1 year data collected for 12 houses in each class from LESCO website as shown in Table 5. $192 \mathrm{kWh}$ energy is consumed in 5 Marla house, $261 \mathrm{kWh}$ in 7 Marla, $305 \mathrm{kWh}$ in 10 Marla and $490 \mathrm{kWh}$ in 1 Kanal House per month.

Table 6 estimates the total energy consumption from all houses. These results are average. 5 Marla houses Class have highest energy consumption which is $114,816 \mathrm{kWh}$ per month. 7 Marla houses have demand of $87,174 \mathrm{kWh}, 10$ Marla 92,720 and 1 Kanal demands 52,430 kWh per month.

Approximately $6.9 \times 10^{-4}$ metric tons of $\mathrm{CO}_{2}$ are emitted for the generation of $1 \mathrm{kWh}$ of electricity (EPA 2005).

So by using Equation 3.1:

$1 \mathrm{kWh}$ of solar energy $=6.9 \times 10^{-4}$ metric tons of $\mathrm{CO}_{2}$ reduction

$39,613,072 \mathrm{kWh}$ of solar energy $=39,613,072 \times 6.9 \times 10^{-4}$ metric tons of $\mathrm{CO}_{2}$ reduction

$=273,330,197 \times 10^{-4}$ metric tons of $\mathrm{CO}_{2}$ reduction

$=27,333$ Metric tons of $\mathrm{CO}_{2}$ reduction

\section{Discussion}

The reason for more energy production from 5 Marla houses comparing to 7 and 10 Marla is, there are more number of houses in 5 Marla class. 1 Kanal houses have maximum energy generation potential because these houses occupy more land. Fifth class E consist of commercial, school and community center buildings, these have high potential because these building have more rooftop space available. Community center and school's

Table 4. Solar power potential estimates for PGSHS Lahore.

\begin{tabular}{ccccc}
\hline Class & House Size & $\begin{array}{c}\text { Total Estimated Roof } \\
\text { Area All Houses }\end{array}$ & $\begin{array}{c}\text { Monthly Potential Total } \\
\text { Area } \mathrm{kWh}\end{array}$ & $\begin{array}{c}\text { Yearly Potential } \\
\text { Total Area kWh }\end{array}$ \\
\hline Class D & 5-Marla $\left(126.47 \mathrm{M}^{2}\right)$ & 6674 & 804,773 & $9,657,278$ \\
Class C & 7-Marla $\left(177.05 \mathrm{M}^{2}\right)$ & 5089 & 613,649 & $7,363,783$ \\
Class B & 10-Marla $\left(252.93 \mathrm{M}^{2}\right)$ & 4860 & 586,035 & $7,032,420$ \\
Class A & 1-Kanal $\left(505.86 \mathrm{M}^{2}\right)$ & 10,212 & $1,231,397$ & $14,776,764$ \\
Class E & Other & 541 & 65,236 & 782,827 \\
& Total & 27,376 & $3,301,090$ & $39,613,072$ \\
\hline
\end{tabular}

Table 5. Electricity consumption of individual house at PGSHS.

\begin{tabular}{cccc}
\hline Sr. \# & House Size & $\begin{array}{c}\text { Average Estimated Electricity Consumption per } \\
\text { house per Month kWh }\end{array}$ & $\begin{array}{c}\text { Monthly Average Potential per } \\
\text { house type kWh }\end{array}$ \\
\hline 1 & 5-Marla $\left(126.47 \mathrm{M}^{2}\right)$ & 192 & 1346 \\
2 & 7-Marla $\left(177.05 \mathrm{M}^{2}\right)$ & 261 & 1837 \\
3 & 10-Marla $\left(252.93 \mathrm{M}^{2}\right)$ & 305 & 1928 \\
4 & 1-Kanal $\left(505.86 \mathrm{M}^{2}\right)$ & 490 & 11,508 \\
\hline
\end{tabular}

Table 6. Electricity consumption of all houses at PGSHS (Source: LESCO).

\begin{tabular}{ccccc}
\hline Class & House Size & $\begin{array}{c}\text { Total Estimated Electricity } \\
\text { Consumption All houses per } \\
\text { Month kWh }\end{array}$ & $\begin{array}{c}\text { Monthly Total Potential all } \\
\text { houses house type kWh }\end{array}$ & $\begin{array}{c}\text { Percentage } \\
\text { consumption }\end{array}$ \\
\hline Class D & 5-Marla $\left(126.47 \mathrm{M}^{2}\right)$ & 114,816 & 804,773 & $14 \%$ \\
Class C & 7-Marla $\left(177.05 \mathrm{M}^{2}\right)$ & 87,174 & 613,649 & $14 \%$ \\
Class B & 10-Marla $\left(252.93 \mathrm{M}^{2}\right)$ & 92,720 & 586,035 & $16 \%$ \\
Class A & 1-Kanal $\left(505.86 \mathrm{M}^{2}\right)$ & 52,430 & $1,231,397$ & $4 \%$ \\
& Total & 347,140 & $3,235,854$ & $11 \%$ \\
\hline
\end{tabular}


all rooftop may be used for PV installation because these roof have no other use and fee. The study area has more energy generation potential than demand. In the long summer days when the energy short fall reaches its peak, solar energy generation would also be at its peak. Furthermore the house owners would get minimum electric bills instead they would get extra income by investing their extra energy in national grid. If all the roof area would utilized the energy would be huge from the study area. A financial model would be proposed for the investment in the study area by different stake holders or energy companies.

\section{Conclusions}

Though small parts of roofs are selected, the energy production is very high. Each 5 Marla house would produce average $1346 \mathrm{kWh}$ energy per month and 7 Marla would produce $1837 \mathrm{kWh}$ per month. $1928 \mathrm{kWh}$ and 11,508 $\mathrm{kWh}$ of energy would be produced by 10 Marla and 1 Kanal houses per month respectively.

This study sought out PV potential from PGSHS Lahore's building's rooftops. This Study provides an overview of PV energy potential. There were two main outputs from this study: 1) the high resolution incoming solar radiations data in study area, and 2) total rooftop area available for PV installation. After studying and analysis, we see that the total photovoltaic potential for electricity generation from the rooftops of PGSHS Lahore is approximately $399,613,072 \mathrm{kWh}$ annually. Comparing with energy consumption of society, this would be approximately $11 \%$ of total energy consumption of society. There will be more energy generation if we utilize all rooftop areas.

There is $4.01 \mathrm{kWh} / \mathrm{m}^{2} /$ day energy potential in the study area. According to NREL scale for energy potential, study area lies in good resource potential.

It is not possible to calculate exact capacity for proposed energy generation. We only can estimate from the calculated rooftop area. Many steps were taken to estimate rooftop area by digitations. High resolution imagery was used to digitize rooftops. A field survey was conducted to ensure whether all roofs were flat or tilted. Shadow effect of one roof on another is also avoided by only digitizing mount areas. And minimum area of roof is utilized.

Total 1443 parcels were digitized from residential, commercial and school buildings in the study area. For exact calculations, all the rooftops were digitized rather than some samples. All the roofs are the same in the same class of houses. Nearly the same area is selected from all rooftops of the same class. From GPS survey, average elevation was calculated in the study area. This helps in estimating the solar radiations potential for all society. There was no slop and aspect in study area's rooftops, so radiations were the same on all roofs and calculation was not complex. A great care was taken during survey, during digitizing rooftops and during analysis.

\section{References}

[1] Rogner, H.-H., Barthel, F., Cabrera, M., Faaij, A., Giroux, M., Hall, D., et al. (2000) Energy Resources. In: Goldemberg, J., Ed., World Energy Assessment: Energy and the Challenge of Sustainability, UNDP, New York, 136-171.

[2] Sustainable Energy Utility Task Force (2008) The Sustainable Energy Utility: A Delaware First. A Report to the Delaware State Legislature by the Sustainable Energy Utility Task Force. http://www.seu-de.org/docs/SEU_Final_Report.pdf

[3] De Vries, B.J.M., van Vuuren, D.P. and Hoogwijk, M.M. (2007) Renewable Energy Sources: Their Global Potential for the First-Half of the 21st Century at a Global Level: An Integrated Approach. Energy Policy, 35, 2590-2610. http://dx.doi.org/10.1016/j.enpol.2006.09.002

[4] PEPCO (2012) View Power Situations. http://www.pepco.gov.pk/pow_situation.php

[5] Arifeen, M. (2013) Can Pakistan Meet Its Energy Needs? The Nation Newspaper, 7. http://nation.com.pk/columns/19-Jul-2013/can-pakistan-meet-its-energy-needs

[6] Khalil, M.S. Renewable Energy in Pakistan: Status and Trends. Pakistan Alternative Energy Development Board, Prime Minister's Secretariat.

[7] Johnson, G. and Armanino, D. (2004) GIS Tools for Community Development Applications. Paper Presented at American Solar Energy Society (ASES) Solar Power 2004 Conference, San Francisco, CA.

[8] Bravo, J.D., Casals, X.G. and Pascua, I.P. (2007) GIS Approach to the Definition of Capacity and Generation Ceilings of Renewable Energy Technologies. Energy Policy, 35, 4879-4892. http://dx.doi.org/10.1016/i.enpol.2007.04.025

[9] Pletka, R., Block, S., Cummer, K., Gilton, K.R.O., Roush, B., Stoddard, L., Tilley, S., Woodward, D. and Hunsaker, M. (2007) Arizona Renewable Energy Assessment. Black \& Veatch Corporation, Overland Park. 
http://www.energy.ca.gov/reti/documents/2007-09 AZ Renewable Energy Assessment.pdf

[10] Broesamle, H., Mannstein, H., Schillings, C. and Trieb, F. (2001) Assessment of Solar Electricity Potentials in North Africa Based on Satellite Data and a Geographic Information System. Solar Energy, 70, 1-12. http://dx.doi.org/10.1016/S0038-092X(00)00126-2

[11] Charabi, Y. and Gastli, A. (2011) PV Site Suitability in Oman Analysis Using GIS-Based Spatial Fuzzy Multi-Criteria Evaluation. Renewable Energy, 36, 2554-2561. http://dx.doi.org/10.1016/j.renene.2010.10.037

[12] Fluri, T.P. (2009) The Potential of Concentrating Solar Power in South Africa. Energy Policy, 37, 5075-5080. http://dx.doi.org/10.1016/j.enpol.2009.07.017

[13] Clifton, J. and Boruff, B.J. (2010) Assessing the Potential for Concentrated Solar Power Development in Rural Australia. Energy Policy, 38, 5272-5280. http://dx.doi.org/10.1016/j.enpol.2010.05.036

[14] Dawson, L. and Schlyter, P. (2012) Less Is More: Strategic Scale Site Suitability for Concentrated Solar Thermal Power in Western Australia. Energy Policy, 47, 91-101. http://dx.doi.org/10.1016/j.enpol.2012.04.025

[15] Paidipati, J., Frantzis, L., Sawyer, H. and Kurrasch, A. (2008) Rooftop PV Market Penetration Scenarios. Subcontract Report for NREL.

[16] Perezi, R., Schlemmer, J., Moore, K. and George, R. (2007) Satellite-Derived Resource Assessment in Afghanistan \& Pakistan in Support of the USAID South Asia Regional Initiative. Subcontract Report for NREL.

[17] Hetrick, W.A., Rich, P.M., Barnes, F.J. and Weiss, S.B. (1993) GIS-Based Solar Radiation Flux Models. American Society for Photogrammetry and Remote Sensing Technical Papers 3, GIS. Photogrammetry and Modeling, 3, 132-143. http://professorpaul.com/publications/hetrick_et_al_1993_asprs.pdf

[18] Hofierka, J. and Súri, M. (2002) The Solar Radiation Model for Open Source GIS: Implementation and Applications. Proceedings of the Open Source GIS-GRASS Users Conference 2002, Trento, 11-13 September 2002. http://www.ing.unitn.it/ grass/conferences/GRASS2002/proceedings/proceedings/pdfs/Hofierka Jaroslav.pdf

[19] Fu, P. and Rich, P. (1999) Design and Implementation of the Solar Analyst: An Arc View Extension for Modeling Solar Radiation at Landscape Scales. Proceedings of the Nineteenth Annual ESRI User Conference, San Diego. http://professorpaul.com/publications/fu_rich_1999_esri.pdf

[20] Lashof, D.A. and Ahuja, D.R. (1990) Relative Contributions of Greenhouse Gas Emissions to Global Warming. Nature, 344, 529-531. http://dx.doi.org/10.1038/344529a0

[21] Martin, P. (2006) Dynamic Life Cycle Assessment (LCA) of Renewable Energy Technologies. Renewable Energy, 31, 55-71. http://dx.doi.org/10.1016/i.renene.2005.03.002 